\title{
PENGARUH SERVICE QUALITY, BRAND IMAGE TERHADAP BRAND LOYALTY DENGAN BRAND TRUST SEBAGAI MEDIASI
}

\author{
Sammy Natanael \\ Program Studi Magister Manajemen Universitas Tarumanagara \\ Sammy.natanae191@gmail.com
}

\begin{abstract}
The purpose of this paper is to explore the direct and indirect influence of service quality and brand image on consumer's brand loyalty with brand Trust as the mediation variable. Data were collected from 189 respondents and 187 responses had been used in this paper. "Service quality" measure used nine-item scale, "brand image" measured used sixitem scale, "brand Trust" and "brand loyalty" measure used five-item scale. All measurement items were measured on five point Linkert-type scales. The four hypotheses in this paper have been tested. Service quality significantly gives positive influence to brand loyalty through brand Trust although service quality doesn't significantly give positive influence to brand loyalty directly. Brand image significantly gives positive influences to brand loyalty directly and through the brand Trust. Brand Trust gives positive influences to brand loyalty.
\end{abstract}

\begin{abstract}
Abstrak : Tujuan dari makalah ini adalah untuk mengeksplorasi pengaruh langsung dan tidak langsung kualitas jasa dan brand image pada brand loyalty konsumen dengan brand Trust sebagai variabel mediasi. Data dikumpulkan dari 189 responden dan 187 tanggapan telah digunakan dalam makalah ini. Ukuran "Service quality" menggunakan sembilan butir pertanyaan, "brand image" yang diukur menggunakan enam butir pertanyaan, "brand Trust" dan "brand loyalty" menggunakan lima butir pertanyaan. Semua butir pertanyaan diukur pada skala lima titik Linkert-type. Keempat hipotesis dalam makalah ini telah diuji. Service quality secara signifikan memberikan pengaruh positif terhadap brand loyalty melalui brand trust meskipun service quality tidak secara signifikan memberi pengaruh positif terhadap brand loyalty secara langsung. Brand image secara signifikan memberikan pengaruh positif terhadap brand loyalty secara langsung dan melalui brand trust. Brand trust memberi pengaruh positif terhadap brand loyalty.
\end{abstract}

Keyword : Service Quality; Brand Image; Brand Trust; Brand Loyalty

\section{PENDAHULUAN}

Menurut Algesheimer (sebagaimana dikutip dari Chinomona, 2016) brand loyalty adalah sikap dimana konsumen mau membeli produk dari suatu brand secara berulang-ulang, atau konsumen mau membeli produk dari suatu brand dengan harga premium dan lebih mahal dibandingkan dengan brand lainnya. Brand loyalty saat ini merupakan strategi marketing yang ampuh untuk bersaing dengan kompetitor. Menurut Huang (2017) brand experience dan brand love mempengaruhi brand loyalty melalui brand Trust. Sementara Chinomona (2016) menyatakan brand image dan brand communication memberikan pengaruh terhadap brand loyalty. Lebih lanjut O'Sullivan, Dagger, dan Chenet (2008) menjelaskan bahwa brand Trust dapat dipengaruhi oleh service quality. Service quality merupakan faktor lain yang dapat mempengaruhi brand loyalty. Service quality merupakan penilaian konsumen terhadap pelayanan jasa yang diberikan oleh penyedia jasa atau produk. Ketika konsumen menerima jasa yang diberikan oleh penyedia jasa diatas apa yang diharapkannya, konsumen akan merasa puas dan akan menggunakan produk atau jasa dari brand tersebut. Ketika konsumen telah menggunakan produk atau jasa yang diberikan secara berulang-ulang, dan konsumen tetap merasa puas akan layanan yang diberikan, kepercayaann konsumen terhadap produk tersebut akan meningkat. Kepercayaan tersebut akan membantu terbentuknya brand loyalty. 
Di sisi lain, brand image dan service quality juga akan mempengaruhi terbentuknya brand trust. Brand image dan service quality yang baik yang berada diatas ekspetasi konsumen akan meningkatkan kepercayaan konsumen terhadap brand tersebut. Konsumen yang percaya terhadap sebuah brand, akan bersedia untuk melakukan pembelian atau penggunaan brand tersebut secara berulang-ulang, dan memberikan komentar positif terhadap brand tersebut. Oleh karena itu dapat dikatakan Brand image dan Service quality mempengaruhi brand loyalty dengan melalui brand Trust sebagai mediasi.

\section{TINJAUAN PUSTAKA}

\section{Service Quality}

Menurut Parasuraman, Zeithaml, dan Berry (1985) service quality didefinisikan sebagai "comparison between expectations and performance" (p.42). Definisi lain diungkapkan oleh Lewis dan Booms (sebagaimana dikutip dari Parasuraman et al., 1985) menyatakan bahwa service quality is a measure of how well the service level delivered matches the expectations. Dari uraian di atas dapat disimpulkan bahwa kualitas jasa merupakan perbandingan antara jasa yang diberikan dengan jasa yang diharapkan oleh konsumen.

\section{Brand Image}

Menurut Keller (1993) brand image merupakan "perceptions about a brand as reflected by the brand associations held in consumer memory" (p.3). Definisi lain menurut Aaker (1991) mendefinisikan bahwa brand image adalah "anything in consumer's memory linked to a specific brand" (p.109). Dari uraian definisi di atas dapat disimpulkan bahwa brand image merupakan persepsi konsumen terhadap suatu brand yang terbentuk dari ingatan konsumen terhadap identitas brand tersebut

\section{Brand Trust}

Menurut Lau dan Lee (1999) brand Trust merupakan "willingness to rely on a brand" (p.343). Menurut Chaudhuri (2001) mendefinisikan brand Trust sebagai "consumer willingness to rely on the ability of the brand to perform its state function" (p.82). Dari uraian di atas, dapat ditarik kesimpulan bahwa brand Trust adalah kemauan untuk mengandalkan atau mengkonsumsi suatu brand berdasarkan kepercayaan terhadap brand tersebut. Peneliti ingin meneliti tentang pengaruh brand image dan service quality terhadap brand loyalty dengan mediasi brand Trust dengan model penelitian yang disajikan dalam gambar 1 .

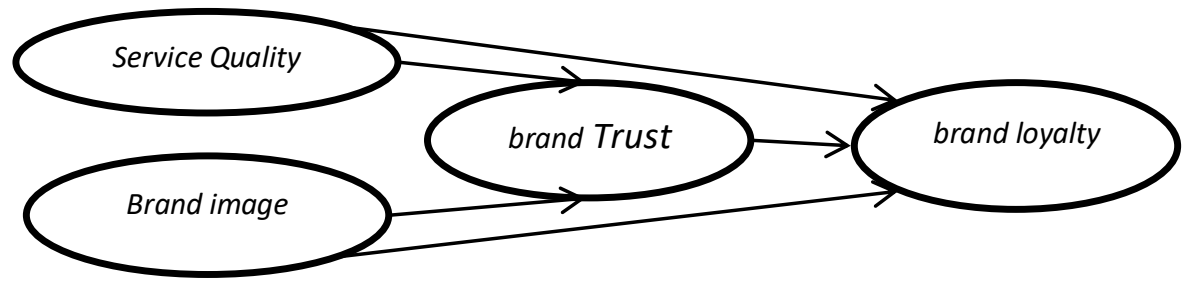

Model Penelitian

Gambar 1.

\section{Kaitan a) brand image, b) service quality dan brand Trust}

Menurut Porter dan Claycomb (1997) Brand image akan merangsang sisi kognitif dari konsumen. Hal ini didukung oleh penelitian yang dilakukan oleh Alhaddad (2015) yang menunjukan bahwa brand image memberikan pengaruh yang positif terhadap brand trust. Brand image yang baik akan meningkatkan kepercayaan secara kognitif terhadap brand tersebut. Kepercayaan dalam waktu yang lama, dan pembelian yang berulang ulang akan memberikan emosi dan sikap positif terhadap brand tersebut. Hal ini dapat meningkatkan kepercayaan afektif dari suatu brand. Menurut O'Sullivan et al. (2008) service quality memberikan dampak positif terhadap brand Trust. Selanjutnya Moorman (1992) menyatakan bahwa ketika konsumen puas terhadap reliability, tingkat respon, dan empati dari sebuah 
perusahaan, konsumen akan meningkatkan kepercayaannya terhadap perusahaan tersebut. Berkaitan dengan hal ini, reliability, tingkat respond dan empati merupakan bagian dari service quality, dengan kata lain dapat dinyatakan bahwa service quality dapat membantu terbentuknya brand trust. Berdasarkan uraian di atas, maka hipotesis (H1a dan H1b) penelitian adalah:

H1a: Service quality berpengaruh positif terhadap brand trust

H1b: Brand image berpengaruh positif terhadap brand trus

\section{Kaitan a) brand image, b) service quality dan brand loyalty}

Menurut Aaker (1992) brand image dapat membantu ingatan konsumen terhadap informasi yang diberikan oleh suatu brand, menjadi dasar perbedaan satu brand dengan brand lain. Berkaitan dengan hal tersebut, perbedaan yang dihasilkan dari brand image suatu brand dapat memberikan alasan kepada konsumen untuk membeli dan menciptakan perasaan positif terhadap brand tersebut. Menurut Aaker (1992) service quality memberikan nilai tambah untuk suatu brand. Service quality yang baik akan memberikan alasan kepada konsumen untuk membeli suatu brand dan membuat perbedaan dari kompetitor lainnya. Berkaitan dengan hal tersebut, purchase intention merupakan salah satu ciri dari brand loyalty, dengan kata lain dapat dinyatakan bahwa service quality memberikan pengaruh positif terhadap brand loyalty. Jika layanan yang diberikan kepada konsumen sesuai atau bahkan berada diatas ekspetasi dari konsumen, maka konsumen akan merasa puas dan akan meningkatkan kesetiaan konsumen terhadap suatu brand. Berdasarkan uraian di atas, maka hipotesis penelitian ( $\mathrm{H} 2 \mathrm{a}$ dan $\mathrm{H} 2 \mathrm{~b})$ adalah:

H2a: Service quality berpengaruh positif terhadap brand loyalty

H2b: Brand image berpengaruh positif terhadap brand loyalty

\section{Kaitan Brand trust dan brand loyalty}

Menurut Huang (2017) kepercayaan terhadap sebuah brand mengacu kepada persepsi konsumen terhadap sebuah brand, apakah brand tersebut reliable dan atau bertanggung jawab terhadap apa yang brand tersebut tawarkan. Hal tersebut berkaitan dengan elemen kognitif dari konsumen. Jika konsumen memiliki perasaan aman, dan percaya terhadap brand tersebut, konsumen akan membeli brand tersebut bahkan akan melakukan pembelian berulang yang merupakan salah satu karakteristik dari brand loyalty (behavioral loyalty). Dengan pembelian berulang, dan kepercayaan konsumen serta pengalamannya terhadap suatu brand, attitudinal loyalty konsumen akan berkembang. Oleh karena itu, secara langsung brand trust akan mempengaruhi brand loyalty. Berdasarkan uraian di atas, maka hipotesis penelitian (H3) adalah:

H3: Brand trust berpengaruh positif terhadap brand loyalty

\section{Kaitan a) Brand image dan b) service quality dan brand loyalty melalui brand trust}

Penelitian yang dilakukan oleh Huang (2017) menunjukan bahwa brand trust dapat menjadi mediasi dari terbentuknya brand loyalty. Berkaitan dengan penelitian ini, brand loyalty didalam penelitian ini meliputi loyalitas secara sikap dan perilaku, dimana ditunjukan dari pembelian yang dilakukan berulang, serta komitmen konsumen terhadap suatu brand yang dipengaruhi oleh kepercayaan konsumen terhadap brand tersebut.

Selanjutnya penelitian yang dilakukan oleh Chinomona (2013) menyatakan bahwa brand image dapat mempengaruhi brand loyalty, melalui brand trust. Dalam penelitian ini, brand image tidak mempengaruhi brand loyalty secara langsung, akan tetapi brand image mempengaruhi brand loyalty dengan melalui brand trust sebagai mediasi. Hal ini menunjukkan bahwa brand trust mampu memediasi terbentuknya brand loyalty. Berdasarkan uraian di atas, maka hipotesis penelitian ( $\mathrm{H} 4 \mathrm{a}$ dan $\mathrm{H} 4 \mathrm{~b})$ adalah: 
H4a: Service quality berpengaruh positif terhadap brand loyalty melalui brand trust H4b: Brand image berpengaruh positif terhadap brand loyalty melalui brand trust

\section{METODE PENELITIAN}

Penelitian ini,merupakan penelitian yang bersifat deskriptif. Penelitian ini melakukan pengumpulan data dengan menggunakan questionnaires yang disebarkan melalui google form sebagai teknik pengumpulan datanya. Pada penelitian kali ini, populasi yang digunakan adalah seluruh pelanggan salah satu kedai kopi di Indonesia. Untuk pengambilan dilakukan teknik sampling non-probability sampling yakni purposive sampling. Sampel yang digunakan dalam penelitian ini berjumlah 187 orang. Untuk mengukur variabel yang digunakan dalam penelitian ini, seperti: service quality, brand image, brand trust, dan brand loyalty diadaptasi dari penelitian terdahulu dan diukur menggunakan skala linkert lima poin. Tabel 1 menunjukan pengukuran masing masing variabel dan sumbernya. Analisa model penelitian ini dijalankan melalui dua tahapan yakni outer model analysis, dan inner model analysis. Outer model untuk menguji validitas dan reabilitas dari variabel dengan indikator yang digunakan dengan cara menganalisa dua model yakni convergent validity, dan discriminant validity. Inner model analysis Uji model struktural ini dilakukan guna mengetahui pengaruh dari variabel. Uji ini dilakukan dengan cara mengukur beberapa nilai kriteria seperti $R$ Square $\left(\mathrm{R}^{2}\right), Q$ square, $f$ square, analisis t-statistik, pengujian hipotesis dan analisis efek mediasi.

Tabel 1. Variabel dan Pengukuran

\begin{tabular}{|l|c|l|}
\hline \multicolumn{1}{|c|}{ Variabel } & Item & \multicolumn{1}{c|}{ Sumber } \\
\hline Variabel Bebas : & & \\
Service quality, terdiri & & \\
dari : & 3 & Siu, N.Y.M., dan \\
Personal interaction & 3 & Cheung, J.T. (2001) \\
Policy & 3 & \\
Convenience & 6 & \\
Brand image & & \\
\hline
\end{tabular}

Tabel 1. Lanjutan

\begin{tabular}{|l|c|l|}
\hline \multicolumn{1}{|c|}{ Variabel } & \multicolumn{1}{c|}{ Item } & \multicolumn{1}{c|}{ Sumber } \\
\hline $\begin{array}{l}\text { Variabel Terikat : } \\
\text { Brand Loyalty }\end{array}$ & 5 & $\begin{array}{l}\text { Ismail dan Spinelli } \\
(2011)\end{array}$ \\
\hline $\begin{array}{l}\text { Variabel Mediasi : } \\
\text { Brand Trust }\end{array}$ & 5 & Lau dan Lee (1999) \\
\hline
\end{tabular}

\section{HASIL DAN PEMBAHASAN}

Hasil uji hipotesis dapat dilihat pada Tabel 2. Dalam tabel tersebut dapat dilihat bahwa service quality dan brand image memberikan pengaruh positif terhadap terbentuknya brand loyalty melalui brand trust. Akan tetapi secara langsung hanya brand image saja yang memberikan pengaruh positif terhadap terbentuknya brand loyalty.

Tabel 2. Hasil Pengujian Hipotesis

\begin{tabular}{|c|l|l|l|l|}
\hline Hipotesis & Hubungan & $\begin{array}{l}\text { T } \\
\text { Statistics }\end{array}$ & $\begin{array}{l}\text { P } \\
\text { Values }\end{array}$ & Keterangan \\
\hline H1a & Service Quality -> Brand Trust & 3.263 & 0.001 & Didukung \\
\hline H1b & Brand Image -> Brand Trust & 7.661 & 0 & Didukung \\
\hline H2a & Service Quality -> Brand & 1.753 & 0.08 & Tidak \\
\hline
\end{tabular}




\begin{tabular}{|c|l|l|l|l|} 
& Loyalty & & & Didukung \\
\hline H2b & Brand Image -> Brand Loyalty & 2.949 & 0.003 & Didukung \\
\hline H3 & Brand Trust -> Brand Loyalty & 5.25 & 0 & Didukung \\
\hline H4a & $\begin{array}{l}\text { Service Quality - > Brand Trust } \\
->\text { Brand Loyalty }\end{array}$ & 2.712 & 0.007 & Didukung \\
\hline H4b & $\begin{array}{l}\text { Brand Image -> Brand Trust - } \\
\text { > Brand Loyalty }\end{array}$ & 4.163 & 0 & Didukung \\
\hline
\end{tabular}

Hasil pengujian hipotesis H1a dan H1b didukung oleh penelitian dari O'Sullivan et al. (2008) yang menyatakan bahwa service quality secara positif mempengaruhi brand trust dan Alhaddad (2015) menyatakan bahwa brand image memberikan pengaruh positif terhadap brand trust. Dari hasil ini dapat disimpulkan bahwa brand image yang baik akan menaikan tingkat kepercayaan seseorang terhadap suatu brand. Brand image yang baik akan merangsang kepercayaan afektif dan kognitif dari seseorang sehingga dapat membentuk brand trust. Dilain sisi, service quality juga memberikan dampak positif terbentuknya brand trust. Kemudahan transaksi, respond yang cepat dalam pelayanan, dan kepedulian terhadap konsumen merupakan hal yang dapat meningkatkan kepercayaan konsumen terhadap suatu brand.

Sementara untuk hasil hipotesis $\mathrm{H} 2$ a tidak sejalan dengan dengan hasil dari penelitian Nazar, Rashid, dan Islam (2016) yang mengungkapkan bahwa service quality juga memberikan pengaruh positif terhadap brand loyalty dalam bidang usaha makanan cepat saji, akan tetapi peningkatan service quality tidak memberikan pengaruh yang signifikan kepada brand loyalty dibandingkan dengan pengaruh yang diberikan product quality terhadap brand loyalty. Hal ini menunjukkan bahwa peran service quality terhadap usaha tertentu makanan cepat saji atau kedai kopi tidak terlalu signifikan atau bahkan tidak memberikan dampak terhadap terbentuknya brand loyalty. Oleh karena itu peningkatan service quality tidak memberikan pengaruh dalam meningkatnya brand loyalty. Hasil hipotesis $\mathrm{H} 2 \mathrm{~b}$ didukung oleh penelitian yang dilakukan oleh Nazar et al. (2016) yang mengungkapkan bahwa brand image memberikan pengaruh positif terhadap terbentuknya brand loyalty. Brand image membantu konsumen dalam mengingat informasi yang diberikan oleh suatu brand. Hal ini juga merupakan pembeda antara suatu brand dengan brand lainnya. Semakin positif brand image yang dibentuk, maka akan menjadi pertimbangan konsumen untuk memilih brand tersebut. Hal ini dapat menyebabkan terbentuknya brand loyalty.

Selanjutnya hasil pengujian H3 didukung oleh Chinomona (2014) yang menunjukkan bahwa brand trust memberikan pengaruh positif terhadap brand loyalty. Hal ini menunjukkan bahwa perasaan aman, dan percaya terhadap suatu brand, akan meningkatkan loyalitas konsumen terhadap brand tersebut.

Kemudian hasil pengujian $\mathrm{H} 4 \mathrm{a}$ dan $\mathrm{H} 4 \mathrm{~b}$ sejalan dengan penelitian Zehir, Sahin, dan Kitapci (2011) yang mengungkapkan bahwa service quality memberikan pengaruh terhadap brand loyalty melalui brand trust dan Abdullah Alhaddad (2015) yang menunjukkan bahwa brand image memberikan pengaruh terhadap brand loyalty secara langsung dan juga brand image memberikan pengaruh terhadap brand loyalty dengan melalui brand trust sebagai mediasi. Dari hasil uji hipotesis ini dapat disimpulkan bahwa semakin baik service quality dan brand image yang diberikan, kepercayaan terhadap suatu brand akan meningkat. Seiring dengan meningkatnya kepercayaan terhadap suatu brand, loyalitas terhadap brand tersebut pun meningkat. 


\section{KESIMPULAN DAN SARAN}

Berdasarkan hasil analisis data dan kesimpulan yang telah didapatkan, ditemukan bahwa brand image dan service quality yang secara positif memberikan pengaruh terhadap brand loyalty melalui brand Trust. Sedangkan brand Trust sendiri dipengaruhi juga secara positif oleh service quality dan brand image. Berdasarkan hasil ini, maka penulis ingin menyarankan kepada perusahaan untuk terus meningkatkan kepercayaan pelanggan agar dapat menciptakan pelanggan yang memiliki loyalitas terhadap suatu brand. Berdasarkan hal ini, maka sangat disarankan untuk terus meningkatkan kontrol terhadap kebersihan gerai-gerai, dan melakukan upgrade dalam metode pembayarannya, serta terus berinovasi dalam pembuatan produk baru yang dapat memenuhi keinginan banyak konsumen.

\section{DAFTAR PUSTAKA}

Aaker, D.A. (1991), Managing Brand Equity. Free Press. New York. NY.

Alhaddad, Abdullah. (2015). "Perceived Quality, Brand Image and Brand Trust as Determinants of Brand Loyalty." Journal of Research in Business and Management, $3,1-8$.

Chaudhuri, A., \& Holbrook, M. B. (2001). "The Chain of Effects from Brand Trust and Brand Affect to Brand Performance: The Role of Brand Loyalty." Journal of Marketing, 81-93

Chinomona, Richard. (2013). "Brand communication, brand image, and brand Trust as antecedents of brand loyalty in Gauteng Province of South Africa." African Journal of Economic and Management Studies, 7, 124-139.

Huang, Chao-Chin. (2017). "The impacts of brand experiences on brand loyalty: mediators of brand love and Trust.” Management Decision, 55 (5), 915-934.

Ismail, A.R., \& Spinelli, G. (2012). "Effects of brand love, personality and image on word of mouth: The case of fashion brands among young consumers." Journal of Fashion Marketing and Management: An International Journal, 16 ,386-398,

Keller K.L. (1993). "Conceptualizing, Measuring, and Managing Costumer-Based Brand Equity." Journal of Marketing, 57, 1-22.

Lau, G.T., \& Lee, S.H. (1999). "Consumers' Trust in a Brand and the Link to Brand Loyalty.” Journal of Market Focused Management, 4, 341-370.

Maheshwari, V., Lodorfos, G., \& Jacobsen, S. (2014). "A Study of Experience-CommitmentLoyalty Constructs.” International Journal of Business Administration, 5, 13-23.

Morgan, M.R., \& Hunt, S.D. (1994). "The Commitment-Trust Theory of Relationship Marketing." Journal of Marketing, 58, 20-38

Nazar, K.M., Rasheed, S., dan Islam, F (2016). "Corporate Branding, Emotional Attachment, and Brand Loyalty: The case of Luxury Fashion Branding." International Journal of Scientific and Research Publications, 6, 151-159. 
O’Sullivan, D., Dagger, T.S., \& Chenet, P. (2010). "Service Quality, trust, commitment and service differentiation in business relationship.” Journal of services marketing. 24. 336-346.

Parasuraman, A., Zeithaml, V. \& Berry, L. (1985). “A Conceptual Model of Service Quality and Implications for Future Research.” Journal of marketing, 49, 41-50.

Porter, S.S., \& Claycomb, C.(1997) "The influence of brand recognition on retail store image", Journal of Product \& Brand Management, 6, 373-387

Zehir, C., Sahin, A., \& Kitapci, H., (2011). "The Effect of Brand Communication and Service Quality In Building Brand Loyalty Through Brand Trust; The Empirical research on Global Brands." Procedia Social and Behavioral Sciences. 24. 12181231. 
